\title{
THE PRINCIPAL FACTORS THAT DRIVE THE ECONOMIC COMPETITIVENESS
}

\author{
Dana-Teodora MIERLUȚ ${ }^{1}$, Adriana GIURGIU ${ }^{2}$ \\ ${ }^{1}$ Doctoral School of Economics and International Business, The Bucharest \\ University of Economic Studies (ASE București), Bucharest, Romania \\ ${ }^{2}$ Doctoral School of Economics and International Business, The Bucharest \\ University of Economic Studies (ASE București), Bucharest, Romania; \\ Department of International Business, Faculty of Economic Sciences, University of \\ Oradea, Oradea, Romania \\ dana.mierlut@gmail.com \\ adrianagiurgiu@gmail.com
}

Abstract: The Economic Competitiveness is a term which has a significant importance in the welfare of a country and also in the development of a company. A simple definition says that competitiveness is the ability of a state or even a firm to put in the market products and services that have a high quality and, in addition, are competitive with others in terms of price; being able to bring some profit after covering all the expenses appeared in the production process. The main objective of this paperwork is to emphasize which factors drive the evolution of the economic competitiveness. It is influenced by internal factors - in a microeconomic perspective -, as well as external factors - in a macroeconomic point of view, factors such as: division of labour, specialization, assets (resources), processes and institutions and government policies. The study is based on the specialized literature in the economic field, precisely the one which influence the economic competitiveness. Economic competitiveness is a complicated notion shaped by a multitude of factors, it appears that utilizing multiple or mixed indicators (indexes) of competitiveness is the most relevant technique to estimate its level. Although the traditional theory of comparative advantage controlled global trade thinking for a long time, it is now regarded as an insufficient justification for firms' competitive advantage in today's business climate. Advances in technology and innovation, as well as some environmental resource limitation issues, have generated new options for obtaining, preserving, and also enhancing productivity versus opponents in an incredibly challenging, worldwide economy.

Keywords: driven factors of the economic competitiveness; economic competitiveness; international competitiveness; determinants of competitiveness; competitiveness.

JEL classification: B27; F14; $O 47$.

\section{Introduction}

We live in a world that promotes globalization and day by day more companies extend their reach beyond the borders of their own national countries. However, there are still many cultural differences from a nation to another and the competition is strong, so a firm must adapt to multiple changes in order to survive in the market or expand its reach to new ones. 
The Economic Competitiveness is a term which has a significant importance in the welfare of a country and also in the evolution of a company. Competitiveness is a word which has its origins in the Classical Latin, "petere" being the meaning of desire, to attack, seek etc, while "con" (the prefix) means together (Siudek and Zawojska, 2014).

A simple definition says that competitiveness is the ability of a state or even a firm to put in the market products and services that have a high quality and, in addition, are competitive with others in terms of price; being able to bring some profit after covering all the expenses appeared in the production process.

In other words, according to the Economic Point's definition, "Competitiveness is the capability a country or company has to achieve profitability in the market in relation to its competitors. Competitiveness depends on the relationship between the value and quantity of the outputs offered and the inputs needed to obtain profitability (productivity), as well as the productivity of the other bidders that exist in the market. The concept of competitiveness can be applied to both a company and a country."

Taking into account the above considerations, the aim of the present paper is to identify and analyze the main factors that drive the economic competitiveness across the globe.

The paper is organised as follows: general literature review on the subject of driven factors of the economic competitiveness, the explanation of some of the most common and important factors, and, in the end, a series of conclusions regarding the driven factors of the economic competitiveness.

\section{The Driven Factors of the Economic Competitiveness}

The factors which influence the level of competitiveness mostly consist of price, quality, logistics and image. Furthermore, the machineries and other technologies, as well as the human know-how, represents the competitive advantages.

Another perspective points out the fact that competitiveness is the one that really sustain the location economy, having the power to improve or decrease the standard of living of the population.

"From a macroeconomic perspective it looks at the drivers of a location's rate of underlying trend growth. The perspective taken is focused on the medium-to longterm: how strong are the underlying fundamentals, and how can they be improved? Wages and costs are in this view assumed to revert 'automatically' to their equilibrium levels. This definition is important for organizations like competitiveness councils that are supposed to focus on long-term growth and prosperity rates. Countries that are losing competitiveness in the sense of slowing productivity dynamics are seen to be exposed to a deteriorating prosperity performance. The literature on growth spurts has shown that the level of sustained productivity growth is what ultimately matters, not the stability or variability of growth rates itself." (Ketels, 2016). 
As we can see in Table 1, the Economic Competitiveness is influenced by internal factors - in a microeconomic perspective -, as well as significant external factors - from a macroeconomic point of view. There are many theorists who strongly agree with each option, usually considering one of them to be the only source of power that keeps the economic competitiveness alive, respectively the actual market still working.

The history proved once and again that none of these apparently solutions are perfect and, in fact, the situation is more nuanced that it may seem. In order for everything to go smoothly in the economy and to have a real growth, there is always some kind of a mix of microeconomic and macroeconomic elements present on the market.

The specialists in this domain developed multiple interesting concepts and theories regarding the determinants of the Economic Competitiveness which combined are really useful and some of them continue to have an impact even after several centuries.

We can identify here the work of Adam Smith - division of labour, specialization, and also the theory of Michael Porter about the importance of the firms within the international markets, how they are the only meaningful actors competing in this considered "game", and also his well known theory of the five forces (supplier power, buyer power, barriers to enter the market, threat of substitutes and rivalry), which is still pretty accurate in the nowadays' economic competitiveness.

From a macroeconomic perspective, the law, political institutions and the monetary and fiscal policy are the agents which really have an impact on the economy, minimizing the influence of the companies.

We are going to analyze in the following pages some elements of each point of view and demonstrate that they are actually strong just when their powers are combined. It is impossible to increase a nation's welfare through the economic competitiveness only using to invest in physical capital or with the help of state institutions and government policies / regulations.

Table 1: Determinants of competitiveness found in empirical research

\begin{tabular}{|c|c|}
\hline Determinants & Authors \\
\hline Division of labour, specialization & Classical economics: Smith (1776) \\
\hline & Neoclassical theories: Schumpeter \\
Investment in physical capital & (1950) \\
& Swan (1956) \\
\hline & Horne et al. (1992) \\
& Barney, Hansen (1994) \\
Carney (1998) & Khalil (2000) \\
& Barney et al. (2001) \\
& Nivievskyi, von Cramon-Taubadel \\
& Zho08) \\
& Zhang (2013) \\
\hline & O'Farrell, Hitchens (1988) \\
& Porter (1990) \\
& Kanter (1993) \\
& Chaharbaghi, Feurer (1994) \\
\hline
\end{tabular}


TOM XXX, 2 ${ }^{\text {nd }}$ Issue, December 2021

\begin{tabular}{||c|c|}
\hline Determinants & Authors \\
\hline & Sushil, Kak (1997) \\
& Notta, Vlachvei (2010) \\
& Atkinson, Andes (2011) \\
& Reeves, Deimler (2011) \\
& Altomonte, Ottaviano (2011) \\
& Buga, Meyer (2012) \\
& Ollo-López, Aramendía- \\
& -Muneta (2012) \\
& Forsman et al. (2013) \\
\hline & Scott, Lodge (1985) \\
& Buckley et al. (1988) \\
& Schwalbach (1991) \\
& Dou, Hardwick (1998) \\
& Man et al. (2002) \\
& Dangelico, Pujari (2010) \\
& Bosma et al. (2011) \\
& Mullen, Keogh (2013) \\
\hline \multirow{3}{*}{ Fupporting and related industries and } & Boonzaaier, von Leipzig (2009) \\
clusters & Altomonte, Ottaviano (2011) \\
& Ketels et al. (2012) \\
& Delago et al. (2013) \\
\hline & Andrén, Oxelheim (2002) \\
& Nivievskyi, von Cramon-Taubadel \\
& (2008) \\
& Gulev, Dukaric (2010) \\
& Brunet (2012) \\
& Gulati et al. (2013) \\
\hline &
\end{tabular}

Source: Siudek, T., Zawojska, A. (2014), p. 101-102

\section{Division of labour, specialization}

The Specialization refers to the concentration of resources and work in a specific area or field, which gives the best results. It is a very profitable technique not only in terms of money, but also when we talk about the time invested in the process and the expertise of different workers.

Taking the last element into consideration, the expertise, we have the Division of Labour. This strategy is going hand in hand with Specialization, because, after we choose the area in which to put all of our financial and physical efforts, it is important to break down the actual work in multiple tasks. This way, every worker does whatever is good at.

While Specialization may be used in all kinds of activities, Division of Labour is mostly known for its contribution to the sectors with mass-production - assembly lines. In this concept is perfect if everyone does a simple job, being considered that there is no need to complicate things. Being capable of understanding a part of the total work may reduce costs in a long run, because the work becomes more efficient. 


\section{Investment in physical capital}

The investment in physical capital is one of the main three factors of production, together with land and labour. It consists of assets, such as the building of a company or the vehicles and machineries used to facilitate the process of production. Their principal characteristic is that assets are fixed capital, which means they cannot be consumed during the production of the merchandise (goods and services).

This is one of the first aspects a new company should focus on, way before orders start to appear. Usually, physical capital requires a huge amount of money, which is invested at the beginning of the business. It depreciates among the time if the selling process proves to be profitable.

Also, it is very important to mention that the value of the physical capital may vary over time, because it tends to depend on every change that happens within the organization (not necessarily big ones) and even on the fluctuations of the prices in the market.

\section{Assets (resources)}

According to some specialists in the economic field, the assets of a country or even a company are those which influence the output and, furthermore, the level of competitiveness of that particular entity in relation to others.

We have to agree with them at least in a partial way, because we cannot really produce anything if we do not have resources. In order to have an output, it is necessary to provide an input.

As simple as the definition from above may seem, it represents in fact the whole idea that Horne, Barney, Khalil and many others like them tried to explain through all kinds of complex theories. The assets or resources are: size of agricultural holding, human resources, technology, social responsibility and trust and trustworthiness.

This is how we get to a simple and logical conclusion: it is impossible for a country (or anyone) to compete in the international market without having anything to offer for sale.

\section{Processes}

As the definition says, a process is „a systematic series of actions directed to some end”; ,a continuous action, operation, or series of changes taking place in a definite manner". (Online Dictionary). This is what many economists, such as Michael Porter, Tony Atkinson and Aspasia Vlachvei, believed to be the essential determinant of the Economic Competitiveness.

It is true in some way, exactly as in the case with the resources. We cannot sell a product if we do not put the resources (assets) through a complex process of production and other stages. Sometimes it is an entire procedure and other times everything happens quite easy, it depends on the products or services involved. However, regardless of the details of production, there is always a process involved. 
The processes may be: strategic management (for example, competencies and quality, flexibility and adaptability), human resources - from workforce mobilization to brain drain and brain gain, technological innovations, actual manufacturing and even marketing campaigns. (Siudek and Zawojska, 2014).

In other words, the processes represent a simple link in the chain. A market can function only when all the aspects are in order and respect their own place, which means they value each other and understand the importance of each factor.

\section{Firm's performance}

Profitable companies are an important component for developing countries. Many economists compare them to a machine in terms of determining their economic, sociological, and political growth. To thrive in a highly competitive marketplace, every company should perform under performance-based conditions.

Firm performance has recently become a popular topic in strategic management research, and it is regularly employed as a dependent variable. Despite the fact that it is a widely held concept in academia, there is little agreement on how to define and quantify it. (Taouab and Issor, 2019)

Anyway, some authors accentuate the elements of the firm's performance. Siudek and Zawojska (2014) mention, for example, Bosma et al. (2011) and Mullen (2013) having the attention on productivity, while Buckley et al. (1988), Dou (1998) and Dangelico (2010) paying tribute to product differentiation and range. Also, there are others, like Porter (1990), Pace (1996) and Scott (1985) focusing on prices and costs or like Mehra (1998), pointing out the importance of the share of the market.

\section{Supporting and related industries and clusters}

Clusters are geographically concentrated groups of interconnected businesses and organizations in a specific industry. Clusters are made up of a variety of interconnected industries and other competitive organizations. Suppliers of specialist inputs such as parts, machines, and services, as well as providers of specialized infrastructure, are among them. Clusters frequently extend downstream to distributors and consumers, as well as laterally to complementary product manufacturers and organizations in industries with similar talents, technology, or inputs.

Clusters can be found in almost every national, regional, state, and even urban economy, especially in more developed countries. Silicon Valley and Hollywood are two of the most well-known clusters in the world. Clusters are not exactly unusual; they are extremely common, and here lies a dilemma: in a global market, the durable competitive advantages largely lay in local activities, relationships, and motivation that foreign competitors cannot replicate.

It's crucial what occurs within organizations, but clusters show that the immediate business environment beyond the companies is just as significant. Despite compelling evidence that innovation and market dominance in so many areas are strongly represented-whether it's entertainment in Hollywood, finance on Wall Street, or consumer electronics in Japan-this importance of locations has long been disregarded. 
Clusters have an impact on competitiveness both within the countries, including across national frontiers. As a result, new objectives emerge for all company leaders, not only those that usually compete on a worldwide scale. Clusters provide a new mindset about place in general, questioning much of the common interpretation on how businesses should be organized, how academics may lead to competitive performance, and how governments can support economic growth. (Porter, 1998)

\section{Institutions and government policies}

The institutions and government policies are a sensitive point in the Economic Competitiveness sphere. This happens because the government of a country has permanently the power to introduce some policies or regulations that may affect the companies.

Of course, there are two possible outcomes when the government and other influential institutions apply policies which impact the economy: they could add taxes or some regulations in order to favour the national production or break them down in order to increase competition (between local businesses or international players). Considering the fact that most of the countries have an important tendency toward globalization nowadays, the second option is more applicable and viable.

However, taking into account this information, we can affirm without any doubt that the state institutions and government policies are directly involved in Economic Competitiveness.

\section{In conclusion}

The study highlights that economic competitiveness is influenced by many factors, such as division of labour, investment in physical capital and institutions and government policies. There are involved both microeconomic and macroeconomic factors.

Although the traditional theory of comparative advantage controlled global trade thinking for a long time, it is now regarded as an insufficient justification for firms' competitive advantage in today's business climate. Advances in technology and innovation, as well as environmental resource limitation issues, have generated new options for obtaining, preserving, and enhancing productivity versus opponents in an incredibly challenging, worldwide economy.

Recognizing the major elements that support or restrict enterprises' capacity to compete is necessary, even the first step of the process, for developing government actions to increase business competition. However, these criteria can vary based on the country, area, or sector. According to the research, one of the biggest barriers to gaining competitiveness for the least-developed nations is the difficulties in setting up their economic environments to the global competitiveness factors.

Because competitiveness is a complicated notion shaped by a multitude of factors, it appears that utilizing multiple or mixed indicators (indexes) of competitiveness is the most relevant technique to estimate its level. 


\section{References}

1. Ketels, C. (2016), Review of Competitiveness Frameworks, Dublin, National Competitiveness Council, [Online]: https://www.hbs.edu/faculty/Publication\%20Files/Review\%200f\%20Competitivenes s\%20Frameworks\%20 3905ca5f-c5e6-419b-8915-5770a2494381.pdf.

2. MindTools (2016), Analyzing Competitiveness Using Porter's Five Forces Model, [Online]: https://www.mindtools.com/pages/article/newTMC 08.htm.

3. Online Dictionary: https://www.dictionary.com/browse/processes.

4. Porter, M. (1998), Clusters and the New Economics of Competition, Harvard Business Review, [Online]: https://hbr.org/1998/11/clusters-and-the-neweconomics-of-competition.

5. Siudek, T., Zawojska, A. (2014). Competitiveness In The Economic Concepts, Theories And Empirical Research, Warsaw, Oeconomia 13 (1), [Online]: http://www.oeconomia.actapol.net/pub/13 1 91.pdf.

6. Taouab, O., Issor, Z. (2019), Firm Performance: Definition and Measurement Models, Morocco, ENCG

Kenitra,

[Online]: http://dx.doi.org/10.19044/esj.2019.v15n1p93. 